\title{
História do Tempo Presente, narrativas e homossexualidade: os casos de Pierre Seel e Rudolf Brazda como sobreviventes do Holocausto
}

\author{
History of the Present Time, narratives and homosexuality: the cases of Pierre Seel and Rudolf Brazda as Holocaust \\ survivors
}

Tiempo presente Historia, narrativas y homosexualidad: Ios casos de Pierre Seel y Rudolf Brazda como supervivientes del Holocausto

Mateus Henrique Siqueira Gonçalves

Universidade de Brasília - Brasil

Brasília, Brasil

mateussiqueira85@gmail.com

\section{RESUMO}

O presente artigo expõe a construção do ambiente que possibilitou a manifestação das narrativas homossexuais de Pierre Seel e Rudolf Brazda enquanto sobreviventes do Holocausto; por quais meios eles emergem e se relacionam com a História do Tempo Presente e como essa categoria pode ser encarada como uma forma de expressão da experiência traumática. Para que isso fosse possível, cotejei ambas as obras ("Eu, Pierre Seel, deportado homossexual" e "Triângulo Rosa: um homossexual no campo de concentração nazista") em uma leitura atenta aos marcadores sociais comuns para esses sujeitos. Os pontos de contato comungados entre os documentos analisados, uma autobiografia de 1994 e uma biografia de 2010, foram privilegiados para a redação deste texto. O objetivo principal desta análise foi compreender como as narrativas testemunhais desses indivíduos foram consolidadas em espaços de luta sócio-política, reivindicando lugar legítimo no âmbito público, reparações e direitos à memória, à verdade e à justiça. Dentre os resultados, constatase a realidade da homofobia institucional como empecilho direto no reconhecimento das vítimas homossexuais da perseguição, deportação, encarceramento e extermínio protagonizado pelos nazistas. Mesmo décadas depois da reconstrução da Europa e, consequentemente, desnazificação do seu território, vítimas como os triângulos rosa permaneceram à margem social, encaradas por Estado e sociedade como criminosos comuns.

Palavras-chave: História do Tempo Presente; Testemunho; Homossexualidade; Nazismo; Holocausto.

\section{ABSTRACT}

This article exposes the construction of the environment that made possible the manifestation of the homosexual narratives of Pierre Seel and Rudolf Brazda as Holocaust survivors; by what means they emerge and relate to the History of the Present Time and how this category can be seen as a form of expression of the traumatic experience. For this to be possible, I compared both works ("Eu, Pierre Seel, deportado homossexual" and "Triângulo Rosa: um homossexual no campo de concentração nazista") in a careful reading of the common social markers for these subjects. The points of contact shared between the analyzed documents, an autobiography from 1994 and a biography from 2010, were privileged for the writing of this text. The main objective of this analysis was to understand how the testimonial narratives of these individuals were consolidated in spaces of socio-political struggle, claiming a legitimate place in the public sphere, reparations, and rights to memory, truth, and justice. Among the results, there is the reality of institutional homophobia as a direct obstacle to the recognition of homosexual victims of persecution, deportation, imprisonment, and extermination carried out by the Nazis. Even decades after the reconstruction of Europe and, consequently, the denazification of its territory, victims such as the pink triangles remained on the social margin, seen by the State and society as common criminals.

Keywords: History of the Present Time; Testimony; Homosexuality; Nazism; Holocaust. 


\section{RESUMEN}

Este artículo expone la construcción del entorno que hizo posible la manifestación de las narrativas homosexuales de Pierre Seel y Rudolf Brazda como sobrevivientes del Holocausto; por qué medios surgen y se relacionan con la Historia del Tiempo Presente y cómo esta categoría puede verse como una forma de expresión de la experiencia traumática. Para que esto fuera posible, comparé ambos trabajos ("Eu, Pierre Seel, deportado homossexual” y "Triângulo Rosa: um homossexual no campo de concentração nazista") en una lectura atenta de los marcadores sociales comunes para estos sujetos. Los puntos de contacto compartidos entre los documentos analizados, una autobiografía de 1994 y una biografía de 2010, fueron privilegiados para la redacción de este texto. El principal objetivo de este análisis fue comprender cómo las narrativas testimoniales de estos individuos se consolidaron en espacios de lucha sociopolítica, reivindicando un lugar legítimo en la esfera pública, reparaciones y derechos a la memoria, la verdad y la justicia. Entre los resultados, se encuentra la realidad de la homofobia institucional como obstáculo directo para el reconocimiento de homosexuales víctimas de persecución, deportación, encarcelamiento y exterminio llevado a cabo por los nazis. Incluso décadas después de la reconstrucción de Europa y, en consecuencia, de la desnazificación de su territorio, víctimas como los triángulos rosas quedaron en el margen social, vistas por el Estado y la sociedad como delincuentes comunes.

Palabras clave: Historia del Tiempo Presente; Testimonio; Homosexualidad; Nazismo; Holocausto.

\section{Introdução}

O tempo que não passa é um universo de clausura para uma categoria de pessoas específicas que também foram atingidas pelos nazistas, os homens homossexuais. Indivíduos que após a guerra foram submetidos ao silêncio quase de maneira crônica, impedidos de testemunhar por muitos fatores, entre eles, talvez o maior e mais central de todos: as leis anti-homossexuais que permaneceram em vigor mesmo após a desnazificação da Europa. Desde o final do século XIX, em 1871, quando os territórios de cultura e língua germânica foram instituídos como nação, criando a Alemanha, a homossexualidade foi incluída em código da lei no Parágrafo 175 enquanto crime por ser considerada ato antinatural, equiparada à zoofilia (Whisnant, 2016, p. 19). Portanto, prescrevendo prisão e perda dos direitos políticos (Setterington, 2017, p. 44-45).

Adolf Hitler, em 1935, um ano após mandar expurgar do Partido Nazista a figura militar da alta cúpula do Reich, Ernest Röhm, e mais 300 homens da SA, os camisas parda, reformulou a lei do Parágrafo 175. Esse fato entrou para a História como a “Noite das Facas Longas" (Whisnant, 2016, p. 212). A datar desse momento, a perseguição, deportação, encarceramento e extermínio dessa comunidade foi elevada a um nível sistêmico (Schlagdenhauffen, 2018, p. 7-8). A homossexualidade masculina, portanto, foi tomada definitivamente enquanto um crime contra a nação ariana, pois, era enquadrada como ameaça direta à reprodução dos cidadãos legítimos do Terceiro Reich. A homossexualidade, assim como o judaísmo, percebida enquanto um problema racial que somente a reversão e/ou aniquilação seria viável (Borrilo, 2010, p. 82-83; Setterington, 2017, p. 47).

Como o extermínio dentro da lógica nazista não é uma ideia concebida de imediato, isto é, é um processo laboratorial dos horrores que se mostram efetivos ou não, a homossexualidade também passou por experimentações. Ainda nos anos 1930, os nazistas incluíram os homossexuais nos programas de eugenia, em primeiro momento, focando em tentativas frustradas de reabilitar homossexuais à heterossexualidade apoiadas em torturas pseudocientíficas com a administração de hormônios. Depois, para completar o projeto dos "estágios de reabilitação", alguns homossexuais foram obrigados a perpetrarem atos sexuais com mulheres dentro dos campos de concentração. Tendo respostas negativas a essas empreitadas, optou-se pela castração química, posteriormente, ao extermínio, de fato (Borrilo, 2010, p. 83). 
Imersos nessa catástrofe homofóbica, lado singular do Holocausto, encontramos dois sobreviventes que inauguram tempos e diálogos distintos dentro da História do Tempo Presente. Pierre Seel, um francês alsaciano sobrevivente não somente do campo de concentração de Schirmeck-Vorbrück na França ocupada e colaboracionista, mas, igualmente sobrevivente da guerra, pois foi enviado ao front oriental para morrer em combate com os soviéticos; se enquadra em um movimento de resistência sócio-política que ressurge ainda no imediato dos anos 1980 em busca do direito à memória, à verdade e à justiça, porém, seu apogeu só se concretizará em 1994. Rudolf Brazda, por outro lado, um tchecoslovaco de criação alemã, sobrevivente do campo de concentração de Buchenwald na Alemanha, se encontra nos anos 2010, colhendo os frutos da luta homossexual empreendida décadas anteriores. Aqui, neste artigo, proponho expor a construção da atmosfera de exposição dos homossexuais enquanto vítimas legítimas do Holocausto, por quais meios eles insurgem na História do Tempo Presente e, como em termos historiográficos, esse tempo é uma expressão da experiência traumática.

Diante das catástrofes do século XX, as noções historiográficas e os sentidos que damos as documentações são ressignificados. Segundo Henry Rousso, o conceito de historiador-perito surge nesse momento:

[...] encarregado de ajudar na redefinição de fronteiras e tornando se, por esse fato, ator, ainda que menor, de um processo em curso, ou ainda a da testemunha, sobrevivente de uma experiência de violência extrema que fala em nome de seus camaradas desaparecidos e se impõe no espaço público em osmose ou em conflito com os discursos acadêmicos, igualmente impregnados da experiência direta da guerra (Rousso, 2016, p. 219).

Nos é imposta uma obrigação política e moral de mudança dentro da academia (Rousso, 2016, p. 219), a reestruturação do ofício historiográfico se faz necessária para acompanhar uma nova demanda de gente e narrativas que se relacionam de maneira nova com o passado, com o tempo vivido. O Holocausto, catástrofe moderna mais documentada da história humana, nos faz repensar métodos, linguagens, e a confecção de documentações a parte daquelas tidas enquanto oficiais. É o "sentimento profundo de que não existe regra que possa ser aplicada de uma forma automática e sistemática, que tudo é uma questão de dosagem, tato e compreensão" (Prost, 2008, p. 135) que levam os historiadores a lidarem com as gamas heterogêneas e complexas de produções que surgem a partir do Holocausto, fazendo urgente problemáticas novas e inesperadas. A História do Tempo Presente se abre para essa nova estrutura de exame. "O surgimento dos grandes crimes de massa, com a primazia do extermínio dos judeus, desempenhou, sem dúvida nenhuma, um papel central na importância concedida à história recente" (Rousso, 2016, p. 220).

Os judeus conseguiram um lugar próprio dentro da memória do Holocausto após décadas de luta social, política e, sobretudo, institucional, levando a cabo seus depoimentos a um nível que se inaugurou a "era da testemunha" (Wieviorka, 2006), majoritariamente ancorados nos julgamentos de nazistas e nas representações audiovisuais ocidentais sobre os campos de concentração e extermínio. Tamanha é a importância dessa institucionalização do testemunho que Annette Wieviorka defende a ideia da era testemunhal ter alcançado seu ápice em relação ao testemunho oral das vítimas baseadas no julgamento de Eichmann em Jerusalém em 1961:

[...] Enquanto o processo de Nuremberg consagrara o privilégio do escrito, o de Eichmann marca o triunfo do depoimento oral. O desejo de instrumentalização do processo ocorrido em Jerusalém como exemplo para a juventude no novo Estado de Israel é nitidamente expressa pelo mestre de obras Gidéon Hausner e para isso, ele procede a "uma verdadeira seleção" para preparar melhor o processo. Enquanto que 
em Nuremberg toda a atenção era voltada para os carrascos, os mais altos dignatários da barbárie nazista, ao contrário, em Jerusalém o personagem do carrasco Eichmann se apaga. Só resta dele a imagem de uma simples engrenagem mecânica, a atenção se desloca inteiramente para o volume das vitimas (Dosse, 2013, p. 308).

Como podemos perceber, são décadas depois do fim da guerra e, consequentemente, da libertação dos campos, desnazificação da Europa ocupada, etc, que o mundo se abre ao olhar mais profundo da catástrofe nazista. Foi preciso um movimento institucional no campo político e jurídico para que as testemunhas judias do Holocausto conseguissem ser viabilizadas. Mas ainda assim, outras tantas comunidades com suas particularidades permaneceram à margem desse processo de monumentalização da memória, afinal, muitos outros foram os perseguidos, deportados, encarcerados e exterminados pelos nazistas e, majoritariamente, os judeus são as vítimas que ilustram a vitrine dessa tragédia.

François Dosse afirma que é desde o final dos anos 1970 que a História do Tempo Presente ganha força com "o acesso ao acontecimento através do testemunho oral, enquanto arquivo ou origem" (Dosse, 2013, p. 307). Nesse sentido, corroboro, em parte, com a visão de alguns historiadores sobre definir a História do Tempo Presente "em termos de temporalidade própria da existência de um indivíduo enquanto estivesse ainda em condições de testemunhar a veracidade do acontecimento em questão" (Dosse, 2013, p. 307). Porém, sabemos que essa noção é falha e momentânea, a História do Tempo Presente não acaba com o fim da vida das testemunhas, os seus relatos as mantém presentes mesmo que os seus corpos já não estejam mais nesse plano. É a consciência que persiste a efêmera vivência humana, através dos seus depoimentos, dos trabalhos que se constituem assentados nos testemunhos, que mantém o passado e seus horrores ainda permanentes em nossa temporalidade.

Durante os anos 1990, há os acertos palpáveis ao que diz respeito às reparações efetivas e simbólicas às vítimas judias do Holocausto (Rousso, 2016, p. 222). E essas ações não são espontâneas, muito menos gratuitas, elas partem do esforço conjunto e exaustivo da comunidade judaica em se fazer valer os seus direitos. Aqui nos é colocado o papel crucial das atividades dos ativistas sócio-políticos, dos testemunhos que se configuram conjuntamente nas associações de vítimas e adentram os tribunais. Os "militantes ferrenhos" (Rousso, 2016, p. 222) demarcam um feito singular ao que concerne atingir o plano da memória coletiva do Holocausto e, fundamentalmente, um novo arranjo no mundo jurídico, político. Afinal, é uma incumbência moral e política que os Estados envolvidos nos crimes perpetrados contra a humanidade sejam punidos.

\section{Metodologia}

Para que este trabalho fosse possível, foi necessário recorrer a análise de fonte dos documentos produzidos pelos sobreviventes homossexuais Pierre Seel e Rudolf Brazda. Em primeiro momento, traçar um perfil dos tópicos que assemelhavam e distanciavam as obras, os pontos de contato que relacionavam as categorias privilegiadas entre as duas narrativas. A partir disso, particularizei os demarcadores que ambos os sujeitos discutiam as exposições de suas obras e os motivos que os levam a compô-las. Logicamente, o artigo precisa ser um recorte de um documento e um fragmento específico de uma pesquisa, sua exposição de maneira integral não é viável. Por conseguinte, a temática desta produção é a relação entre o oportuno tempo presente da constituição das obras e como os seus indivíduos as alavancam.

O dispositivo representacional desenvolvido e explorado nas grafias de vida, no caso deste artigo, uma autobiografia e uma biografia, nos possibilita meios de enxergarmos uma história a nível macro. As documentações conferidas no campo pessoal contam histórias que ultrapassam as vidas micros, isto é, os mundos particulares, privados. Interligando conceitos e perspectivas da 
História do Tempo Presente derivados das obras de acadêmicos como Henry Rousso, Antoine Prost, François Dosse e Paul Ricœur, em comunhão com as contribuições de gênero e estudos sobre sexualidade conferidas por Michel Foucault, podemos traçar um diálogo historiográfico transdisciplinar com as contribuições de pesquisadores como Márcio Seligmann-Silva, Igor Sacramento e Annette Wieviorka. As noções de trauma e memória emergidas dos documentos produzidos por Pierre Seel e Rudolf Brazda, portanto, conseguem ser elucidadas. O testemunho escrito é a categoria central desta análise e ele só pode ser compreendido por um esforço anterior dos historiadores em abrangerem novas possibilidades de confeccionar a história. A literatura de testemunho, portanto, é uma forma de exibir um trauma social e histórico que durante um longo período de tempo foi negligenciado.

\section{Desenvolvimento}

\subsection{Mídia e literatura de testemunho: a ressonância das vozes do Holocausto}

A modernidade também muda o nosso tempo, as tecnologias favoreceram o interesse acadêmico e popular na maior catástrofe do século passado. "[...] O papel desempenhado pelo cinema, pela televisão, pelo rádio e pelos suportes online" é fundamental nesse diálogo com a História do Tempo Presente. A série televisiva Holocaust (1978), o filme A Lista de Schindler (1993) e a Fundação Shoah (1994), selam os interesses que se abrem à temática do Holocausto. O cineasta Steven Spielberg, após executar seu filme biográfico sobre Oskar Schindler, empresário alemão membro do Partido Nazista que, com seus negócios e influência, conseguiu salvar mais de mil judeus da provável morte nos campos de concentração e extermínio, se preocupou em criar uma organização sem fins lucrativos com o intuito de coletar depoimentos dos sobreviventes do Holocausto (Lerner, 2004, p. 4-5).

A partir desse momento, temos um trabalho de enquadramento sobre a memória coletiva buscando nas memórias individuais dos sobreviventes, logicamente, construir esse mosaico. A Fundação tomava enquanto sobreviventes aqueles:

\footnotetext{
[...] que estiveram em guetos, campos de trabalho, concentração ou extermínio, que se esconderam, viveram sob falsa identidade ou participaram de atividades de resistência. Incluía ainda pessoas que foram de alguma forma perseguidas pela política nazista, tendo estado em território ocupado pela Alemanha entre os anos de 1933 a 1945. Ainda que seu alvo preferencial fosse o registro da experiência dos sobreviventes judeus, posteriormente também foram entrevistados outros grupos perseguidos, tais como ciganos, homossexuais, Testemunhas de Jeová, prisioneiros políticos. Além disto, fazia parte do arquivo o que eles chamavam de "outras testemunhas", ou seja, pessoas que ajudaram a salvar estes grupos e os membros dos exércitos aliados que "libertaram" os campos de concentração no final da guerra (Lerner, 2004, p. 5).
}

Dezenas de países foram envolvidos nesse projeto, implicando no cumprimento de entrevistas gravadas em áudio e vídeo, seguindo as diretrizes dos escritórios regionais em cada localidade (Lerner, 2004, p. 5). Igor Sacramento nos aponta o fato do testemunho ter alcançado, dentro dos empenhos da Fundação Shoah, "dimensões industriais, produzindo mais de sessenta mil testemunhos de vídeo em mais de trinta línguas" (Sacramento, 2018, p. 128). O Holocausto, consequentemente, deixa de ser um banco de dados abstrato, um campo virtual repleto de números, idealizando e formando, então, as particularidades de quem esteve no centro desse extermínio.

Com essa iniciativa a nível global, o genocídio perpetrado pelos nazistas ganha rostos, nomes próprios, histórias individuais, sentimentos que são captados em vídeo e áudio, ao passo que as 
testemunhas se prontificam para lembrar os infortúnios que os acometeram. O testemunho é codificado (Sacramento, 2018, p. 130), passa pelas mãos de terceiros, é enquadrado em modelo previamente pensado, seguindo rígido protocolo da Fundação Shoah, porém, ainda assim, se faz popular, inteligível e viável ao grande público.

Além do audiovisual, temos uma outra categorização testemunhal: a literatura. Esse tipo de agrupamento testemunhal precede o movimento do audiovisual. Logo nos primeiros anos depois da Segunda Guerra Mundial temos sobreviventes que conseguem escrever e publicar suas memórias em formatos de narrativas autobiográficas (Sacramento, 2018, p. 127), como o judeu italiano Primo Levi que em 1947 publicou “É isto um homem?” na Itália. Contudo, esse movimento se mostra pouco significativo, não havia espaço de procura e escuta por esses testemunhos, o que levou grande parte dos sobreviventes a um silêncio na vida privada e pública. Sendo exceção, a França, onde uma produção escrita obteve volume considerável no imediato do pós-guerra (Sacramento, 2018, p. 217).

A segunda "era da testemunha":

[...] mais literária, é a das histórias publicadas cerca de dez anos após o retorno. Sobrepostos a essas obras literárias estão os testemunhos que passaram a ser frequentemente utilizados para complementar o trabalho de pesquisa documental de historiadores e juristas. Esse período culmina com o julgamento de Eichmann em 1961. As testemunhas de guerra falam antes das comissões de inquérito de natureza jurídica ou histórica. A pessoa privada, no testemunho, tende a desaparecer atrás dos fatos, cuja verdade deve ser restaurada. Aqui, o testemunho é codificado, orientado inteiramente para a administração da prova: a irrupção da emoção é considerada um embaraço (Sacramento, 2018, p. 217).

Porém, é a literatura de testemunho, construída sobre as subjetividades dos sujeitos e as objetividades da História que se procura alcançar com os relatos, que nos interessa neste artigo. Esse movimento que alicerça, em parte fundamental, a História do Tempo Presente, inaugurando uma nova perspectiva para se olhar o século XX, dialoga com a noção grega de testis, indicando a ação do "depoimento de um terceiro em processo" (Seligmann-Silva, 2003, p. 373), isto é, o olho que tudo vê de maneira clara e absoluta é capaz de pontuar um testemunho sobre o acontecimento (Seligmann-Silva, 2005, p. 79). Entretanto, os sobreviventes do Holocausto, de modo específico, se enquadram na noção grega de supertes, pois são aqueles que, além de estarem ali e verem com os próprios olhos, atravessam uma "provação" (Seligmann-Silva, 2005, p. 374).

Escrever sobre o evento-limite, tratar sobre a "provação", utilizando da escrita performática do "eu” como meio de romper uma dor incomensurável, uma profunda cisão, é uma prática que nos remete à Antiguidade Clássica (Rabinow \& Dreyfus, 1995, p. 271-272), podendo ser conferida até mesmo na Torá, no Antigo Testamento da Bíblia cristã, quando os judeus clamam que o Sagrado Ihes vingue de todos os males que seus escravizadores lhes impuseram. A escrita dolorosa do "eu" é um meio de permanecer vivo, de lembrar os que ainda virão sobre o que aconteceu aos seus antepassados.

Nesse sentido, o testemunho tem tanto uma dimensão psicanalítica, de se auto analisar, auto resolver, auto se encontrar com um passado traumático para perlaborar, com início na atmosfera do luto, o que de fato lhe ocorreu enquanto fenômeno estagnador (Rosa, 2018, p. 295); quanto de se auto identificar. A identidade não é somente uma finalidade, mas uma fatalidade. Assim, ela dá novos sentidos aos que ficam depois de sobreviverem ao Holocausto. Essa nova identidade está enraizada, primordialmente, no trauma social e histórico. 


\subsection{Movimentos reivindicatórios para a demarcação de memória em prol da identidade homossexual pós-Holocausto: caminhos para a comunicabilidade}

Em 1994, Pierre Seel, publicou sua autobiografia com a colaboração de escrita e pesquisa historiográfica, documental e periódica de Jean Le Bitoux, em língua francesa, intitulada Moi, Pierre Seel, déporté homosexuel (Eu, Pierre Seel, deportado homossexual). Em 2010, Jean-Luc Schwab, publicou em mesmo idioma a biografia de Rudolf Brazda, Itinéraire d'un triangle rose (Triângulo rosa: um homossexual no campo de concentração nazista). Ambas trazem uma noção não somente da escrita do "eu", colocando os indivíduos homossexuais em posição de protagonismo e destaque absoluto, mas, sobretudo, com um apoio documental no texto final. Somente o testemunho não bastava e, aparentemente, não fornecia credibilidade suficiente, era preciso recorrer ao artifício da exposição documental para que os leitores verificassem por si só as bases que constituem, em parte, esses trabalhos. Essa ação foi empreendida para que não houvesse dúvidas sobre a veracidade dos fatos ali narrados. Portanto, as duas obras, carregam digitalizações e impressões dos documentos oficias, como ficha de encarceramento no sistema concentracionário, carteira de identidade, certificado de transferência e soltura, bem como fotos, cartas íntimas de familiares, entre outros.

Em primeiro momento, é interessante notarmos como as obras de Pierre Seel e Rudolf Brazda dialogam precisamente com o seu tempo em caráter de revisitação da memória, tempo de escrita e espaço de publicação. Os próximos, como conceitua Paul Ricœur:

[...] são aqueles que me aprovam por existir e cuja existência aprovo na reciprocidade e na igualdade da estima. A aprovação mútua exprime a partilha da afirmação que cada um faz de seus poderes e de seus não-poderes, o que chamo de atestação em Si mesmo como um outro. O que espero dos meus próximos, é que aprovem o que atesto: que posso falar, agir, narrar, imputar a mim mesmo a responsabilidade de minhas ações (Ricœur, 2007, p. 142).

Acima disso, "tonar-se próximo", ainda segundo Paul Ricœur, é "sentir-se próximo" (Ricœur, 2007, p. 141). São esses indivíduos que se prestam ao compadecimento das desventuras alheias que dão possibilidades de estreitamento das relações com os outros. Jean Le Bitoux, jornalista, homossexual ativista da causa, dono do periódico abertamente político pró causa homossexual, Gai Pied, encaminha o trabalho de Pierre Seel, cumprindo papel de colaborador intelectual de sua obra. As notas de rodapé, do testemunho autobiográfico de Seel, são feitas por Jean Le Bitoux. Uma colaboração que necessitou dos esforços de comunicação com as produções acadêmicas e jornalísticas do período sobre a temática abordada por Pierre Seel: a perseguição, deportação, encarceramento e extermínio de homossexuais pelo Terceiro Reich. Por outro lado, temos JeanLuc Schwab, advogado, jornalista, escritor, homossexual igualmente ativista da causa, à época do encontro com seu biografado, Rudolf Brazda, ocupava cargo de chefia regional na Alsácia da Fondation pour la Mémoire de la Déportation (Fundação pela Memória da Deportação). Esses, portanto, são os próximos que encaminham as condições de comunicabilidade desses dois homossexuais sobreviventes do Holocausto.

O documento autobiográfico de Pierre Seel nos traz uma dimensão de querer se fazer enxergar além da catástrofe nazista aos homossexuais. Não é por acaso o seu esforço de revisitar as longínquas memórias da sua infância e adolescência, expor sua constituição familiar, desde o encontro de seus pais por intermédio de um pároco local até o momento da chegada dos nazistas e sua queda, aos 18 anos de idade pelo Parágrafo 175, na França ocupada e colaboracionista. O outro documento, a biografia de Rudolf Brazda, também percorre o mesmo trajeto iniciado por Pierre Seel. Por que é tão relevante sabermos as suas vivências e, consequentemente, memórias 
pregressas antes do contato com as forças do Terceiro Reich? Isso pode ser considerado uma forma de humanizar o itinerário desses homossexuais. É preciso que se tenha noção clara de suas vidas banais, cotidianas, tão imersas de preconceitos e prazeres como qualquer outra do século passado. A identificação chama o leitor a querer descobrir o que aconteceu com esses sujeitos, por quais meios foram engolidos pela máquina de perseguição e morte nazista.

O prefácio da tradução brasileira da obra de Pierre Seel é assinado por Márcio Seligmann-Silva, à época, professor livre-docente da área de Teoria Literária da Unicamp, intitulado "Pierre Seel: um sobrevivente da dor e do silêncio" (Seligmann-Silva, 2012, p. 11). É imprescindível que se tenha muito bem esclarecida a noção dolorosa do testemunho que vem adiante. Maurice Blanchot diz que: "Tudo o que se refere a Auschwitz requer angústia e silêncio" (Dosse, 2013, p. 309). Se partirmos da ideia de Auschwitz enquanto uma metáfora do horror indizível dos campos de concentração e extermínio, logo, podemos entender Pierre Seel enquanto uma vítima legítima "da dor e do silêncio".

E até que ponto essa catástrofe é, de fato, incomunicável? Mesmo que os sobreviventes estejam pairando sobre esse lugar da não comunicabilidade total, eles expressam uma vontade absoluta de se fazerem crer. E seus empenhos conseguem por romper essa zona grossa de silenciamento compulsório. No caso de Pierre Seel essa questão é ainda mais complexa. Ao retornar das violências impostas pelos nazistas, Seel se vê obrigado ao silêncio por um pacto familiar liderado por seu patriarca. O exercício da sexualidade, em termos gerais, já era encarado enquanto uma prática ilegítima fora de um compromisso matrimonial heterossexual, sendo esse tópico voltado à homossexualidade, então, o tabu se alarga. Michel Foucault ao tratar sobre a repressão sexual diz: "[...] decerto, como condenação ao desaparecimento, mas também como injunção ao silêncio, afirmação de inexistência e, consequentemente, constatação de que, em tudo isso, não há nada para dizer, nem para ver, nem para saber" (Foucault, 2020, p. 8).

São as convenções estabelecidas dentro da família conjugal que instauram "o direito de falar, reservando-se o princípio do segredo" (Foucault, 2010, p. 7). Colocando, assim, a sexualidade em modo de confisco. Uma vez que a sexualidade de Seel, encarada "por natureza", experiência desviante, também é tipificada enquanto crime. Seu delito não é somente uma razão legal de culpa e sofrimento, mas é igualmente uma transgressão espiritual, é um pecado que precisa ser escondido. O sigilo absoluto da sua sexualidade em conjunto da homofobia leva Pierre Seel ao encarceramento da sua agonia. Seel, como aponta Márcio Seligmman-Silva, “em boa parte de sua narrativa aparece como um "sem lugar" (Seligmann-Silva, 2012, p. 15), mas progressivamente junto dos seus próximos, no tardio do pós-guerra, vai se estabilizando em um ambiente de acolhimento que sua existência seja amparada.

O processo de conquista desse lugar de aceitação, de fala, só foi possível com a comunhão dos seus iguais. São os homossexuais do seu tempo, especificamente falando dos anos 1980-1990, que alavancam a figura de Pierre Seel e o seu testemunho. Em 1981, após ter contato com o testemunho do austríaco Josef Kohout, publicado sob pseudônimo de Heinz Heger e escrito pelo jornalista Hans Neumman, The man with the pink triangle (1994), despertou em Seel a necessidade de testemunhar. Ele afirma:

Esse foi o verdadeiro início de tudo o que veio depois. Percebi que havia um combate a vencer. Testemunhar, era necessário que me atravesse a testemunhar, mesmo que anonimamente. Era eu o único, nesse caso? Também queria saber, encontrar outras testemunhas, pois quem grita sozinho é rapidamente suspeito. E essa suspeita faz muito mal (Seel, 2012, p. 135). 
Porém, somente depois da fala pública do bispo de Estrasburgo, Léon Arthur Elchinger, em 1982, que Seel decidiu formalizar publicamente a sua história de terror nas mãos dos nazistas em uma carta aberta ao bispo e à imprensa. O estopim que o empertigou de cólera foi o seguinte pronunciamento do religioso: "Eu considero a homossexualidade uma doença. Eu respeito os homossexuais da mesma forma como respeito os doentes. Mas se eles querem transformar sua doença em saúde, eu não concordo" (Seel, 2012, p. 137). Para Pierre Seel, foi esse tipo de posicionamento que levou centenas de homossexuais às prisões, aos campos de concentração e extermínio (Elídio, 2010, p. 16). E essa ideia da homossexualidade enquanto doença e perversão social devia ser combatida.

Dominque Fernandez escreveu, em 11 de dezembro de 1982, no jornal Gai Pied:

Realizados em particular ou em público, esses discursos fazem mal e devem ser denunciados e combatidos em todos os lugares, não importam as circunstâncias. A autoridade moral em que pode prevalecer a fala de um bispo reforça essa gravidade [...] Luto já muitos anos contra essas palavras, essas atitudes vergonhosas, desesperadas, maldosas. Meus textos são desse combate (Seel, 2012, p. 172).

Pierre Seel, por sua vez, foi enfático na carta aberta ao monsenhor Elchinger:

Decidi dar o meu total apoio às numerosas vozes de todos aqueles e aquelas que se sentiram ofendidos pela sua declaração de 8 de abril de 1982. Vítima do nazismo, denuncio publicamente, com todas as minhas forças, que tais discursos favoreceram e justificaram o extermínio de milhões de doentes por razões políticas, religiosas, raciais ou de comportamento sexual. Não sou um doente e não padeço de nenhuma doença. Não desejo retornar às enfermarias onde curaram a minha homossexualidade, mais precisamente em um local que não fica longe da capital alsaciana. Foi em 1941. Eu só tinha dezoito anos. Detido, torturado, golpeado, preso, internado fora de toda jurisdição, sem nenhuma defesa, nem processo, nem julgamento. Estou muito cansado essa noite por me lembrar de todas as torturas morais e físicas e os sofrimentos indescritíveis e inexprimíveis que então suportei. Desde então, toda a minha vida foi vivida na terrível dor compartilhada com minha família por causa dessa detenção arbitrária. Sua declaração de 8 de abril de 1982 despertou em mim um amontoado de lembranças atrozes e decidi também, aos cinquenta e nove anos, sair do anonimato. Por toda minha vida e até hoje, eu não conheci o ódio por ninguém. $\mathrm{E}$, no entanto, sofrendo do desamparo profundo no qual nos deixa essa homofobia sempre presente, estremeço pensando em todos os homossexuais desaparecidos e em todos aqueles que, no mundo, infelizmente, ainda são torturados e exterminados como tantas outras minorias (Seel, 2012, p. 173).

Esta carta é datada de 18 de novembro de 1982, porém, foi publicada pelo Gai Pied Hebdo na edição n. 47, em 11 de dezembro daquele ano. Sua carta é um clamor por reconhecimento e, ao mesmo tempo, a concretização de uma luta sócio-política contra a homofobia. A contar desse acontecimento, Pierre Seel toma o testemunho enquanto uma causa moral, perlaborar a sua dor como maneira de buscar incansavelmente reparações, tanto a nível jurídico, quanto histórico. A carta aberta de Pierre Seel foi divulgada, em primeira instância, para seus familiares e, em seguida, encaminhada ao bispo, à mídia popular e à imprensa homossexual. Essa polêmica, por fim, acabou nos tribunais:

Nesse dia, o "acusado Elchinger, Léon Arthur”, foi representado pelo seu advogado. Como o procurador, esse último declarou que todas as suas denúncias eram inaceitáveis. O tribunal decidiu a seu favor: "As declarações reportadas não visaram nenhuma pessoa designada ou identificável pelo nome." Teriam feito o mesmo se fossem declarações antissemitas? Mas a lei não contempla a homofobia. Os 
autores da denúncia, que queriam, à época, modificar a lei francesa em relação a esse ponto, chegaram até o Supremo Tribunal. Em vão, pois, no final das contas, foram condenados a 30 mil francos de multa por terem difamado o bispo. E seu último recurso no Tribunal Europeu revelou-se infrutífero. Apesar dos poucos ecos que suscitou a minha carta aberta ao prelado, eu senti-me libertado de um pesado segredo (Seel, 2012, p. 138).

Após esse imbróglio, Seel se tornou uma figura conhecida na mídia francesa, deu entrevistas na televisão, nos jornais e nas rádios. Suas primeiras ações o levaram a ter problemas no casamento e no âmbito trabalhista, porém, houve reconhecimento do seu infortúnio por parte significativa da comunidade ao redor. O próprio monsenhor Elchinger chegou a lhe escrever uma carta, como Seel mesmo ressaltou, "cheia de humanidade" (Seel, 2012, p. 139), na esperança de haver reconciliação. Desse momento em diante, começou a frequentar assiduamente os grupos ativistas da causa homossexual, testemunhou oralmente em diversas ocasiões. Tomou para si a causa de fazer visível a deportação por homossexualidade, requisitando legitimidade a si e aos seus iguais (Seel, 2012, p. 139).

Mesmo com os esforços que apreendeu, com as comunicações que exerceu na mídia, com as pessoas da sociedade civil, com os grupos sócio-políticos homossexuais, com suas diversas iniciativas de pleitear espaço no campo político e jurídico, Pierre Seel termina seu livro com a angústia latejante de ainda não ter sido oficialmente reconhecido enquanto um homossexual deportado politicamente pelos nazistas. Uma vítima, como qualquer outra, da barbárie hitleriana. Seu último capítulo, "O testemunho doloroso", não trata da idealização, execução e publicação da obra, mas, sim, de sua busca incansável por reparação, direito à memória, verdade e justiça.

O documento oficial que lhe foi entregue pelo Ministério da Justiça é datado de 13 de maio de 1941, nele, consta a informação da Gestapo de transferir Seel da prisão de Mulhouse para o campo de concentração de Schirmeck-Vorbrück (Seel, 2012, p. 177). Para a justiça francesa somente esse documento não é prova capaz de lhe garantir reconhecimento e, consequentemente, reparações legais, era necessário que houvesse, ao menos, duas testemunhas oculares de sua passagem pelo campo (Seel, 2012, p. 147). Aos 70 anos, idade que marca parte da escrita e publicação de sua obra, Pierre Seel ainda era um sujeito rompido pelo nazismo que não tinha conseguido provar legalmente o seu direito à reparação efetiva do Estado.

Sua autobiografia, portanto, é um documento que procura instigar a busca da verdade, tanto a nível popular quanto acadêmico. É preciso que a sociedade, de modo geral, se interesse por esse trauma, por essa catástrofe. Uma fonte percebida enquanto um observatório sobre a homofobia pré nazismo, durante e pós desnazificação da Europa. Pierre Seel, com seu testemunho, nos atesta as incapacidades da justiça, das instituições públicas e democráticas de ampararem legalmente os homossexuais, vítimas políticas do horror nazista. A homofobia institucional, resquício autoritário do século passado, é o grande empecilho que Seel encontrou no âmbito legal para provar a sua deportação por homossexualidade.

Porém, Tiago Elídio, de maneira primorosa, nos aponta como é importante e fundamental a demarcação da memória homossexual do Holocausto ancorada nos esforços apreendidos por Pierre Seel e seu testemunho autobiográfico:

A publicação de seu livro foi um passo muito importante nessa luta. Em 1995, um ano depois do lançamento do livro, recebeu, finalmente, sua carteira de deportação. Sua autobiografia, desde então, foi republicada quatro vezes na França. No exterior, foi traduzida nos EUA, na Alemanha, na Espanha e na Rússia. Estima-se que a tiragem dessas edições estrangeiras seja de 20 mil exemplares. Foi feita também uma versão 
teatral na Alsácia. Além disso, Seel participou constantemente de programas de rádio e TV para falar sobre o tema, e saiu em reportagens da mídia impressa. Foi também um dos que deram seu depoimento no documentário americano "Parágrafo 175", realizado por Rob Epstein e Jeffrey Friedman, lançado em 2000. Seu livro também inspirou o telefilme francês "Amor em tempos de guerra" ("Um Amour à taire"), de Christian Faure, exibido pela primeira vez em 2005, e o documentário "Amants des hommes" (“Amante dos Homens”, em tradução livre), de Isabelle Darmengeat, lançado em 2006. Portanto, o testemunho de Seel foi decisivo na questão da visibilidade, da memória e do reconhecimento dos homossexuais como vítimas do nazismo (Elídio, 2010, p. 89).

Esses resultados são frutos da tamanha potência de Pierre Seel com seu brado por justiça, verdade, reconhecimento e reparação. Assim, tornando-se um rosto do terror nazista aos homossexuais. O Estado francês reconheceu em abril de 2001 as perseguições que os homossexuais sofreram durante a Segunda Guerra Mundial, o Estado alemão em novembro do ano anterior (Elídio, 2010, p. 89). Em 2005, Jacques Chirac, ocupando o cargo de presidente da França, lembrou as vítimas homossexuais do Holocausto na cerimônia do Dia Nacional da Lembrança da Deportação (Elídio, 2010, p. 90). Mesmo ano que marca o falecimento, aos 82 anos, de Pierre Seel. Como ressaltou Tiago Elídio: “[...] depois de muito lutar pelo reconhecimento oficial, pôde, enfim, descansar em paz" (Elídio, 2010, p. 90). Seel alcançou um lugar de destaque sólido:

[...] Em fevereiro de 2008, foi inaugurada, na cidade francesa de Toulouse, uma rua que leva seu nome e contém uma placa informativa de que se tratou de um deportado francês por homossexualidade. Além disso, no último dia 15 de maio de 2010, foi inaugurada em Mulhouse a primeira placa francesa em homenagem às vítimas homossexuais. Outra está prevista para ser inaugurada no campo de Struthof durante o outono europeu. Também nesse ano de 2010, foi lançado um filme inspirado na história de Seel, "L’Arbre et la Forêt” (“A Árvore e a Floresta”, em tradução livre), de Olivier Ducastel e Jacques Martineau (Elídio, 2010, p. 90).

Rudolf Brazda, em contrapartida do percurso de Pierre Seel, preferiu continuar em silêncio por razões afetivas. Depois da guerra, se estabeleceu na Alsácia, na cidade natal de Pierre Seel o que é uma grande coincidência -, ali, encontrou o amor de sua vida. Seu companheiro, Edi, bem mais jovem que ele, entrou em sua trajetória no carnaval de 1950. Juntos, eles tiveram uma longa vida feliz, compartilhando sentimentos, histórias e aventuras pela Europa. Por pedido de seu companheiro, para que Rudolf fosse preservado de supostas retaliações por conta de sua deportação por homossexualidade, Brazda preferiu optar pelo silêncio. Eles jamais oficializaram sua relação com um casamento civil, porém, permaneceram unidos até a morte de Edi, aos 73 anos, em novembro de 2003 (Schwab, 2011, p. 167).

Somente depois dos seus 95 anos de idade, Rudolf Brazda foi descoberto pela mídia, consequentemente, rompendo seu anonimato de décadas. Em um artigo do jornal francês L'Alsace, de 29 de junho de 2008, Jean-Luc Schwab soube da existência do "alemão [...] gay e mártir dos nazistas" - como caracterizou o jornal (Schwab, 2011, p. 11). Procurado por Schwab, nasceu uma frutífera amizade e parceria para termos acesso à biografia dessa vida tão fascinante e, como Pierre Seel, auxiliadora para alargar o escopo da história do Holocausto. Como aponta Jean-Luc Schwab: “[...] surgia de repente a oportunidade de encontrar uma rara testemunha. Além disso, uma testemunha cuja experiência ainda não havia sido contada...” (Schwab, 2011, p. 11).

Após ter colhido os depoimentos orais de Brazda, seus familiares, amigos e colegas que dividiam as lembranças da família Brazda e dos sofrimentos que Rudolf passou sob a égide do Terceiro Reich, Schwab sentiu que precisava de mais material para que a biografia fosse concretizada. 
Em busca de blindar a narrativa de suspeitas Schwab peregrinou pela Europa atrás dos museus, memoriais, arquivos, enfim, os espaços de memória que guardassem a documentação necessária para se escrever uma obra de fôlego sobre a vida desse sujeito.

Nos agradecimentos do livro ele cita os arquivos pelo qual pesquisou, entre eles o Memorial de Buchenwald (Alemanha) e os Arquivos de Pilsen no depósito de Klášter-Nepomuk (República Tcheca), cita os nomes dos responsáveis por esses locais e sua respectiva preservação documental, e, ao longo da biografia, vez ou outra, faz referências diretas dos lugares que tirou os documentos quando trabalha com os mesmos (Schwab, 2011, p. 5-6). Exemplo disso são os capítulos em que ele trata dos processos judiciais que Brazda enfrentou por parte do Terceiro Reich ao ser incriminado pela lei anti-homossexuais do parágrafo 175. Sobre a temporalidade da publicação original dessa biografia, Karen Pereira da Silva escreveu:

Por ter publicado suas memórias num período de maior abertura e tolerância, Brazda não precisou de pseudônimos nem sofreu ameaças [...] Foi convidado especial de diversas paradas gays pela Europa e esteve presente como convidado de honra em uma das cerimônias anuais de lembrança às vítimas do campo de concentração de Buchenwald. Também prestou suas homenagens em 2010 para Pierre Seel, na ocasião da inauguração do memorial em homenagem a ele em Mulhouse, França (Silva, 2018, p. 22).

Mesmo com a repressão que sofreu, as torturas e o encarceramento, Brazda, ao ser liberto, teve uma "vida plena, com vários amigos e camaradas" (Schwab, 2011, p. 173), sua homossexualidade não era encarada enquanto uma vergonha pelos seus familiares. Sua mãe e irmãos o aceitaram até mesmo antes de ser sucumbido pelo Parágrafo 175 (Schwab, 2011, p. 26). Com a sua sexualidade dissidente muito bem resolvida, ele já tinha vivido outros relacionamentos - chegando até a fazer uma cerimonia de união com um dos seus primeiros amores na casa de sua mãe -, tinha amigos abertamente homossexuais que se "travestiam" em público - assim como ele - (Schwab, 2011, p. 26), o que culmina em uma vivência “dourada” na Alemanha da década de 1920, marcada, exclusivamente, pelo ambiente de liberação da República de Weimar (Gordon, 2006, p. 55). Vivência que difere completamente daquela experimentada por Pierre Seel.

A reparação efetiva também se apresenta como um ponto de importância dentro da obra de Schwab. Ao longo da narrativa fica claro que a sobrevivência de Brazda dentro de Buchenwald dependeu de dois imprescindíveis acontecimentos: o primeiro, sua boa relação com os outros prisioneiros, os comunistas, triângulos vermelhos. O que por si só foi extremamente raro na vida homossexual dentro desse contexto concentracionário; o segundo, portanto, a sua ocupação em Buchenwald: telhador. O ofício de reparar os telhados das construções do campo de concentração, segundo Brazda e Schwab, foi determinante para salvar-Ihe a vida. Sobre a reparação do Estado, Schwab dissertou:

[...] Atualmente, sua aposentadoria alemã considera o tempo de prisão e de trabalho forçado durante sua permanência em Buchenwald. Entretanto, sua demanda de indenização como vítima não judia do nazismo, feita às autoridades alemãs em 1988, foi rejeitada. A justificativa? Ele não executara nenhum serviço braçal que acarretasse uma incapacidade de trabalho suficiente para dar-Ihe direito a ajuda financeira. O fato de ter-se naturalizado francês foi igualmente invocado. Rudolf deveria se dirigir às autoridades competentes na França - o que ele não fez, por pudor e pela dificuldade de falar melhor a língua (Schwab, 2011, p. 170).

Assim como Rudolf Brazda, Pierre Seel também não conseguiu ser contemplado por auxílios indenizatórios. A homofobia institucional, elevada à máxima escala dentro do Estado, impediu o 
acesso à direitos, reparações, uma justiça concreta. Certamente, como vimos ao longo deste artigo, a obtenção das compensações é propositalmente obstruída pelas organizações e associações do Estado. Karen Pereira da Silva nos alerta sobre a incongruência dessas medidas frente aos homossexuais, tendo em vista que "[...] em toda e qualquer indenização por deportação, não era requisito obrigatório que o sobrevivente tivesse sofrido algum dano físico que o incapacitasse de qualquer forma" (Silva, 2018, p. 61).

A aceitação de seu tempo também é salientada em sua obra. Schwab ao descrever a saída do anonimato de Brazda, em 2008, ao saber da construção do monumento que lembra as vítimas homossexuais do Holocausto, no parque Tiergarten no centro de Berlim, Brazda quis se fazer presente. Notando a ausência de sobreviventes homossexuais, pediu para que sua sobrinha que morava em Berlim avisasse que ele estava vivo. Assim, Schwab nos conta sobre a percepção do atual movimento homossexual que Brazda mantinha:

O monumento é um bloco de cimento quadrangular, parecido com aquele do Memorial às Vítimas do Holocausto, do qual ele é quase vizinho. A diferença é a abertura pela qual os transeuntes podem ver um filme projetado sem parar: dois rapazes se beijando. Para Rudolf, uma representação da tortura da Baumhängen talvez tivesse despertado simpatia com mais facilidade - esse filme é mais delicado e pode ferir. Será que isso explica o constante vandalismo contra o monumento? Rudolf faz essa pergunta a si mesmo. Talvez tudo não passe de uma questão de época, e ele confessa não estar muito à vontade com o modo contemporâneo de manifestar o orgulho homossexual, como nas paradas com seus blocos de gente nua... Ele considera, contudo, que os tempos mudaram e que a mentalidade das gerações atuais não está sempre em sintonia com a sua. É preciso que a juventude passe... (Schwab, 2011, p. 174).

De maneira muito semelhante com Pierre Seel, Rudolf Brazda também viveu uma fase de negação da sua sexualidade antes do contato com os nazistas. Por outros motivos, fora de uma lógica cristã-católica de concepção de mundo. Para Brazda, em sua juventude, a homossexualidade era sinônimo de degradação moral e econômica dos homens do seu tempo chagados pelas dificuldades provindas da Primeira Guerra Mundial. Vendo que muitos se colocavam no quadro da prostituição para terem condições mínimas de sobrevivência, Rudolf adquiriu certo grau de repulsa à homossexualidade (Schwab, 2011, p. 24). O que logo se perdeu ao passo de seu amadurecimento e descoberta concreta da sexualidade ao final de sua adolescência e início da vida adulta (Schwab, 2011, p. 23).

Talvez essa seja a maior diferença entre Seel e Brazda, ao que concerne o percurso narrativo e expositivo de suas obras. Pierre Seel, em sua temporalidade, na década de 1990, provavelmente não podia ou não se sentia apto a se dar o benefício de criticar o movimento gay em suas posturas. Com isso, ele embarca nessa luta própria do seu tempo, ele se privilegia das ações dos ativistas e encontra uma base de apoio nesse momento. Faz coro às vozes que estão ao seu redor para, primordialmente, se fazer ouvir e enxergar. Já Rudolf Brazda, como aponta veementemente sua biografia, sequer tinha pretensões de sair do anonimato, ainda à época da escrita de sua narrativa dizia ao biógrafo que se surpreendia com a atenção que recebia da mídia, do movimento homossexual, e se sentia lisonjeado por isso (Schwab, 2011, p. 174). Porém, nem mesmo toda essa atenção o fez ocultar opiniões e posições acerca do movimento. Sendo compreendido por seu autor, essas observações são expostas na obra. Schwab termina a biografia com uma mensagem de apoio e esperança aos homossexuais, tal qual desejava Brazda: 
Sua mensagem às gerações que tiveram a sorte de não conhecer a guerra: não esquecer aqueles que os precederam e sofreram repressão. Aos homossexuais em geral, ele lembra que, se para boa parte do mundo ocidental as leis não mais impõem um modelo de vida que contrarie sua natureza profunda, as conquistas recentes e a maior tolerância estão longe de ser definitivas e usufruídas universalmente. Assim, deve-se continuar alerta, lutar e avançar (Schwab, 2011, p. 176-177).

Um claro chamado a continuidade da luta sócio-política em prol da causa homossexual, da pluralidade humana, é preciso que se tenha atenção redobrada nesses tempos tão obscuros que nos cercam. Tenhamos coragem para mantermos o legado vivo daqueles que vieram antes de nós, pois é na memória dessa gente que sofreu e relatou que conseguimos idealizar um mundo onde a violência da homofobia seja, definitivamente, extinta. Com seu falecimento em 2011, mesmo ano da chegada de seu livro ao Brasil, aos 98 anos de idade, Rudolf Brazda ficou popularmente conhecido como "o último triângulo rosa".

\section{Considerações finais}

As exposições dessas vidas, fundamentadas nos trabalhos das escritas do "eu", possibilitam que os indivíduos Pierre Seel e Rudolf Brazda deixem de fazer parte da margem social pela qual foram impostos coercitivamente. Romper com a lógica de dominação e submissão é, por excelência, tratar do trauma e da memória que acompanha essa estagnação no ambiente público e privado. A visão sobre si é modificada durante o percurso da constituição dessas narrativas. Logicamente, o tempo dessa escrita não é o tempo do sofrimento, é o tempo da busca a favor da resolução e reparação, através do acerto de contas de uma tragédia que ficou ocultada, quase esquecida, durante mais de meio século.

São os motivos exteriores, como a homofobia institucional e estrutural da sociedade europeia, ligadas, obviamente, aos micros entendimentos da vergonha e da culpa no âmbito familiar e afetivo que levaram os sujeitos aqui analisados a um silenciamento de décadas a fio. As complexidades desses encarceramentos psicossociais são esmiuçadas pelos autores e colaboradores diretos das obras. A viabilidade dos textos, sendo assim, é uma consequência de um lento processo de auto aceitação de uma condição humana legítima e, acima disso, da barbárie que se acometeu sobre essa condição. Ou seja, aceitar a homossexualidade e compreender o horror homofóbico.

O testemunho, por conseguinte, passa do campo da auto compreensão para a atmosfera da denúncia. Rudolf Brazda não vive essa inquietação, porém, Pierre Seel a leva até as últimas consequências. É a versão já idosa desse francês alsaciano que não desiste de testemunhar, quer cristalizar um problema político, social, cultural e histórico com o seu depoimento. Um grito por ajuda e por reconhecimento. Através da sua obra e da sua visibilidade na mídia procura pelos seus iguais. Mesmo que em vão, não desiste até o fim da vida de fazer emergir outros como ele, aqueles que comungaram das mesmas tribulações nas mãos dos nazistas.

A História do Tempo Presente procede nesse compasso, providencia forma, traça estrutura, para que se possa comunicar um passado traumático de sujeitos historicamente marginalizados, invisibilizados. A luta sócio-política dos grupos e sujeitos ativistas da causa, a construção da identidade homossexual pós-Holocausto, demarcam a necessidade do fomento de uma nova memória do maior genocídio do século XX. Alicerçadas nessa encruzilhada que as homossexualidades pleiteiam espaço de existência dizível, comensurável, nos campos da política, do judiciário, dos lugares de memória. Entrar para a História é um resultado de luta ativa e efetiva contra a homofobia autoritária e radicalizada pelos fascistas, nazistas e demais atrocidades político-ideológicas que surgem no século passado. Com tamanha dimensão desse grupo de gente marcada pela calamidade e sobrevivência, os historiadores já não podem mais ignorá-los. 


\section{REFERÊNCIAS}

Borrilo, D. (2010). Homofobia: história e crítica de um preconceito. Autêntica Editora.

Dosse, F. (2013). Renascimento do acontecimento: um desafio para o historiador: entre Esfinge e Fênix. Editora Unesp.

Elídio, T. (2010). A perseguição nazista aos homossexuais: o testemunho de um dos esquecidos da memória [Dissertação de Mestrado, Universidade Estadual de Campinas].

Foucault, M. (2020). História da sexualidade I: a vontade de saber. Paz e Terra.

Gordon, M. (2006). Voluptuous panic: the erotic world of Weimar Belin. Feral House.

Heger, H. (1994). The men with the pink triangle: the true, life and death story of homosexuals in the Nazi death camps. Alyson Publications.

Lerner, K. (2004). Holocausto, memória e identidade social: a experiência da Fundação Shoah [Tese de Doutorado, Universidade Federal do Rio de Janeiro].

Prost, A. (2008). Doze lições sobre a história. Autêntica Editora.

Rabinow, P., Dreyfus, H. (1995). Michel Foucault: uma trajetória filosófica. Forense.

Ricœur, P. (2007). A memória, a história, o esquecimento. Editora da Unicamp.

Rosa, J. R. (2018). Trauma, história e luto: a perlaboração da violência. Revista Tempo e Argumento, 10(25), 289-237. https://doi.org/10.5965/2175180310252018289

Rousso, H. (2016). A última catástrofe: a história, o presente e o contemporâneo. FGV Editora.

Sacramento, I. (2018). A era da testemunha: uma história do presente. Revista Brasileira de História da Mídia. 7(1), 125-140. https://doi.org/10.26664/issn.2238-5126.712018

Schlagdenhauffen, R. (2018). Queer in Europe during the Second World War. Conseil de l'Europe.

Schwab, J. (2011). Triângulo rosa: um homossexual no campo de concentração nazista. Mescla.

Seel, P. (2012). Eu, Pierre Seel, deportado homossexual. Cassará Editora.

Seligmann-Silva, M. (2005). Testemunho e a política da memória: o tempo depois das catástrofes. Revista Projeto História. (30), 71-98 https://revistas.pucsp.br/indez.php/revph/article/view/2255/1348

Seligmann-Silva, M. (2003). História, memória, literatura: o testemunho na Era das Catástrofes. Editora da Unicamp.

Setterington, K. (2017). Marcados pelo triângulo rosa. Editora Melhoramentos.

Silva, K. P. da. (2018). Triângulo rosa: a diversidade memorial dos prisioneiros homossexuais do Holocausto [Monografia, Universidade Federal do Rio Grande do Sul].

Whisnant, C. (2016). Queer identities and politics in Germany: A History, 1880-1945. Harrington Park Press.

Wieviorka, A. (2006). The era of the witness. Cornell University Press.

\section{AUTOR}

Mateus Henrique Siqueira Gonçalves. Bacharel e licenciado em História pela Universidade de Brasília (2018). Tem experiência na área de História, atuando principalmente nos seguintes temas: Ditadura Militar brasileira (1964-1985) e História LGBT, com foco em estudos de gênero na área social, cultural e política de lésbicas e travestis. Atualmente, integro o Mestrado em História Social no Programa de Pós-Graduação em História da Universidade de Brasília, bolsista CAPES (2019).

Conflict of interest

No potential conflict of interest is reported by the author.

Funding

No financial assistance from parties outside this article.

Acknowledgments

$\mathrm{N} / \mathrm{A}$

Notes

Este artigo é o resultado final de uma disciplina sobre História do Tempo Presente cursada no Programa de Pós-Graduação em História da Universidade de Brasília (UnB), referente ao primeiro semestre de 2020. Logicamente, ele está intrinsecamente associado com as minhas leituras, análises e escritas desenvolvidas na minha dissertação de mestrado. Portanto, seu conteúdo é uma vitrine da minha pesquisa e, igualmente, seu material é original. 